\title{
Registration and Ranking of Company Charges in Zambia
}

\author{
Akalemwa wa Mubiana ni Munalula Ngenda*
}

\begin{abstract}
This article discusses the effect of the registration requirements under the Zambian Companies Act on the rules for determining priority among company charges in Zambia. In light of the Supreme Court decision in Zambia National Commercial Bank Ltd $v$ Mwila, the article also analyses the scope for applying common law rules on the ranking of charges, vis-à-vis section 101 of the Companies Act.
\end{abstract}

\section{INTRODUCTION}

The statutory registration scheme introduced by section 101 of the Zambian Companies Act 1994 (the Companies Act) ${ }^{1}$ was meant to simplify the complex legal rules pertaining to priority among charges. In so far as it reaffirms the rule that "the first in time prevails" the section restates the common law. However, it amends the common law to the extent that priority is now established by the time of registration. This is now true even among charges in respect of which the equities previously may not have been equal. This legal provision has not completely replaced the common law. It is therefore important to examine the extent to which the nature of any given charge, such as whether it is a floating, fixed or other charge, is still relevant to establishing priority in light of the registration requirements under the Companies Act. ${ }^{2}$

* Lecturer, Brunel Law School, Brunel University, West London, UK; Solicitor, Supreme Court of England and Wales; Advocate, High Court for Zambia and Supreme Court of Zambia.

1 Chap 388 of the Laws of Zambia (1995 edition (revised)).

2 For detailed and further reading on charges, see WJ Gough Company Charges (3rd ed, 2007, Lexis Nexis Butterworths); J Getzler and J Payne (eds) Company Charges: Spectrum and Beyond (2006, Oxford UP); R Calnan Taking Security: Law and Practice (2006, Jordan Publishing); G McCormack Registration of Company Charges (2nd ed, 2005, Jordan Publishing); "The floating charge and the Law Commission consultation paper on registration of security interests" (2003) Insolvency Lawyer 2-13; JH Farrar "Floating charges and priorities" (1974) 38 The Conveyancer 315; "The availability of the floating charge as a security device in the United States" (1928) 28(3) Columbia Law Review 360-66; Law Commission of England and Wales "Registration of security interests: Company charges and property other than land law" (consultation paper no 164, June 2002). The Law Commission recommended that the scheme for registering charges under the Companies Act 1985 should be replaced with a more comprehensive legislative scheme which would eliminate the need to register a charge over land at the Companies Registry, rendering registration at the Land Registry sufficient. 
Section 101(1) of the act provides that: "Subject to any consent (express or implied) given by the person who would otherwise be entitled to priority, charges required by this Part to be registered shall have priority in relation to one another in accordance with the times at which they were lodged."

In Re Sapco Fibreboard $\mathcal{G}$ Wood Products Ltd (in receivership), ${ }^{3}$ an application was made for directions pursuant to section 113 of the Companies Act for the High Court to determine the ranking of two competing charges. The first was a debenture over all movable assets of the company, while the second was a specific charge on plant, machinery and motor vehicles. The debenture was registered earlier than the specific charge. One of the arguments made at the hearing was that section 101(1) was some sort of "first-among-equals" provision which only applied where the charges involved were of the same class, for example where both are either floating charges or fixed charges. The court refused to abide by this logic and stated that section 101(1) is very clear in its terms and, as provided for in subsection 2 , is inapplicable only where priority of charges is determinable in accordance with the provisions of another statute. The court also observed that section 101(1) could not be ousted by the application of common law rules on the ranking of charges. Therefore, a floating charge which was registered earlier under the act could not be outranked by a debenture creating a charge on plant and machinery. ${ }^{4}$

In Zambia National Commercial Bank Ltd v Mwila, the Supreme Court observed that "section 101 is self-explanatory in creating priority among the charges required to be registered under ... the Companies Act". ${ }^{5}$ The court held that this provision did not apply to a mortgage created through the surrender of title deeds. This raises the question as to which rules are applicable for those charges not required to be registered. Also, how would priority be determined in a situation where a non-registrable security is in conflict with a charge that has been registered under the Companies Act? Would the nature of the charges involved have any bearing on the outcome, as is the case at common law? This article attempts to shed some light on these issues.

\section{NATURE OF FLOATING CHARGES}

In Attorney General v Zambia Sugar Co Ltd and Nakambala Estate Ltd it was held that "a floating charge operates as an immediate and continuing charge on the property charged and has the effect of charging all the property in the hands of the borrower at the date of the charge". ${ }^{6}$ The real and intended effect

3 Re Sapco Fibreboard \& Wood Products Ltd (in receivership) - An Application for Directions under s 113 of Cap 388 2001/HPC/0225 (unreported) per Chulu J.

4 In the end, the court held that it was the parties' intention, as evidenced by specific references in the security documents, that the debenture and floating charge should rank equally.

5 SCZ appeal no 94 of 1999 (unreported) (11 November 1999 and 6 April 2000) per Ngulube CJ.

6 Attorney General v Zambia Sugar Co Ltd and Nakambala Estate Ltd (1977) ZR 273 (SC) at 273 per Gardner, acting DCJ. 
remains suspended until the occurrence of some future event. This ordinarily allows the company to deal with and dispose of the charged asset in the meantime. Before it has crystallized, a floating charge is simply an equitable security. ${ }^{7}$ The decision in Zambia Sugar endorsed the formulations of Lord Macnaghten on the nature and effect of a floating charge, the first of which was pronounced in Governments Stock and Other Securities Investment Co v Manila Rly Co Ltd, to the effect that:

"A floating security is an equitable charge on the assets for the time being of a going concern. It attaches to the subject charged in the varying condition in which it happens to be from time to time. It is the essence of such a charge that it remains dormant until the undertaking ceases to be a going concern, or until the person in whose favour the charge is treated intervenes. His right to intervene may of course be suspended by agreement. But if there is no agreement for suspension, he may exercise his right whenever he pleases after default."

The second formulation was enunciated in Illingworth $v$ Houldsworth, where Lord Macnaghten stated:

"I should have thought there was not much difficulty in defining what a floating charge is in contrast to what is called a specific charge. A specific charge I think, is one that without more fastens on ascertained or definite property or property capable of being ascertained and defined, a floating charge, on the other hand, is ambulatory and shifting in its nature, hovering over and so to speak floating with the property which it is intended to affect until some event occurs which causes it to settle and fasten on the subject of the charge within its reach and grasp." 9

As already mentioned, a floating charge does not prevent a company from carrying on its business in the ordinary way. ${ }^{10}$ Generally, this means that a company could even charge its property further in an attempt to secure more funds by way of mortgage or lease. ${ }^{11}$ The company is at liberty to dispose

$7 \quad$ Halsbury's Laws of England (4th ed, Butterworths) vol 16, para 780.

8 (1897) AC 81 at 86, HL.

9 (1904) AC 355 at 358, HL.

10 See Romer LJ in Re Yorkshire Woolcombers Association Ltd (1903) 2 Ch 284 at 295, CA. Also, see JR Lingard Bank Security Documents (3rd ed, 1993, Butterworths) at 155, stating that: "It is of the essence of a floating charge that the company has apparent authority to deal with its assets in the ordinary course of business unless a third party has actual notice of restrictions which preclude this. It does not have authority to undertake transactions outside the ordinary course of business (such as to hive down its assets) and any such transactions if the third party has notice of the irregularity will be subject to the floating charge."

11 Wheatley $v$ Silkstone and Haigh Moor Coal Co (1885) 29 Ch D 715 per North J, where a mortgage made "in the ordinary course of business and for the purpose of the business" was found to be "a good mortgage upon and a good charge upon the property comprised in it", 
of the property charged through sale or exchange, provided that the future event by which the floating charge is caused to settle on the charged property has not taken place. It is commonplace to find restrictions within the charging document with regard to the company's future dealings. Also, the company's authority to deal with its assets in the ordinary course of business may be curtailed where a third party has actual notice of restrictions which prohibit such dealing. ${ }^{12}$ Ultimately, whether or not a charge is a floating charge is a question of fact to be determined by the court.

\section{PERFECTION OF SECURITY INTERESTS}

Perfection consists in the taking of certain required steps, beyond mere attachment, to make a security interest enforceable against a debtor, and also to make it effective against third parties. ${ }^{13}$ In the case of the latter, it is often necessary to perform an act which puts third parties on notice of the security interest. ${ }^{14}$ This additional step is designed to give notice of the security interest to the world and any would-be purchaser or encumbrancer of the secured asset. Taking constructive or actual possession and registration or filing will suffice to give notice to the world and third parties generally. ${ }^{15}$

Possession of security was developed at common law. It is the safest method of perfection as it puts all those dealing with a debtor, of whom possession has been divested, on inquiry and is thus as good as notice to the world at large. ${ }^{16}$ Registration (or filing), on the other hand, is a creature of statute. It is an important mode of perfection for some types of security interests. Although these terms are often used interchangeably, it is more appropriate to refer to "registration" as the lodgement of particulars relating to the security and "filing" as the lodgement of the security instrument itself or a copy of it. ${ }^{17}$ However, it is common for some statutes merely to refer to "registration" of documents ${ }^{18}$ and, as such, this article uses the terms interchangeably unless specified otherwise.

contd

and thus "not subject to the claim created by [a] debenture ... intended to be a general floating security over all the property of the Company".

12 Lingard Bank Security Documents, above at note 10 at 156.

13 R Goode Principles of Corporate Insolvency Law (2nd ed, 1997, Sweet \& Maxwell) at 419-21.

14 Id Commercial Law (3rd ed, 2004, Penguin) at 647.

15 Id at 648.

16 Ibid, stating additionally that, where "a security interest is otherwise unperfected", it may "be perfected vis-à-vis a particular third party by notice to that party or by knowledge aliunde [of that other party] on his part".

17 Report of the Committee on Consumer Credit (1971, HMSO, cmnd 4696) para 5.7.13 (chaired by Lord Crowther). According to Roy Goode, "[t]he distinction is of substance, for the filing of a security instrument or copy is public notice of its contents, whereas according to the orthodox view registration of particulars of the security interest constitutes notice only of the existence of the security and of the other particulars registered": Goode Commercial Law, above at note 14 at 650, n 25 and 664.

18 See sec 4 of the Lands and Deeds Registry Act, cap 185 of the Laws of Zambia. 


\section{REGISTRATION OF CHARGES}

The two schemes for registration of charges referred to here are those provided by the Lands and Deeds Registry and the Companies Registry. ${ }^{19}$ Section 4(1) of the Lands and Deeds Registry Act states:

"Every document purporting to grant, convey or transfer land or any interest in land, or to be a lease or agreement for lease or permit of occupation of land for a longer term than one year, or to create any charge upon land, whether by way of a mortgage or otherwise, or which evidences the satisfaction of any mortgage or charge, and all bills of sale of personal property whereof the grantor remains in apparent possession ... must be registered within the times hereinafter specified in the Registry or in a District Registry: Provided that if a document creating a floating charge upon land has been registered under the [relevant] provisions of the Companies Act, or the Co-operative Societies Act, it need not be registered under the provision of this Part unless and until such charge has crystallized or become fixed."20

The requirement for registration under this provision was considered in Mwila. The key issue in this case was whether a prior equitable mortgage held by an individual to whom the deeds of title had been surrendered, or a later floating charge made in favour of a bank to secure an overdraft, took priority. ${ }^{21}$ The floating charge was created in July 1997 and crystallized with the appointment of a receiver in March 1998. It was registered at both the Lands and Deeds Registry and the Companies Registry. The court held that,

19 Company charges over land which may be registrable under legislation such as the Agricultural Credits Act (cap 224), Co-operative Societies Act no 20 of 1998 or the Trades Charges Act (cap 145) must also be registered under the Companies Act. Note that, where another statute provides rules for determining priority among charges, the rules under the Companies Act do not apply.

20 Cap 185 of the Laws of Zambia.

21 Compare with Re Castell \& Brown Ltd [1898] 1 Ch 315, which involved equitable encumbrances in the form of debentures and an equitable mortgage by deposit of deeds which, though subsequent in date to the debentures, was taken without notice of the debentures. The case held that the bank which held the deeds of title had a stronger equity than the debenture holders and was thus entitled to priority. Also see Perry Herrick $v$ Attwood (1857) 2 De G \& J 21, where a mortgagee left the title deeds to the mortgaged property with the mortgagor, so that the mortgagor could obtain a further mortgage on the same property. It was agreed that the second mortgage would have priority to the first. In fact, the mortgagor obtained two further mortgages and eventually defaulted on all of them. The first mortgagee claimed that his mortgage had priority over at least the third mortgage, if not the second, because it was the earliest and had been created by deposit of title deeds. The court held, however, that the mortgagee had lost his priority by his careless handling of the deeds; as Lord Crownworth LC said: "To hold that a person who advances money on an estate, the title deeds of which are under such circumstances left in the hands of the mortgagor, is not to have preference, would be to shut our eyes to the plainest equity." 
since the equitable mortgage in this case was by way of deposit of title deeds, there was accordingly no document required to be registered under the Lands and Deeds Registry Act.

The Companies Act creates two methods for registering charges. The company is required to maintain its own register where particulars must be entered of all charges over its property. ${ }^{22}$ This register is open for inspection by any member of the public for a fee, while members of the company, its creditors and the Registrar of Companies or his designated agents can make searches for free. The registrar also keeps a register of particulars of all charges affecting the property or undertaking of every company. ${ }^{23}$ Any "floating charge on the whole or part of the undertaking or property of the company" is required to be registered within 21 days of the date on which the charge is created or acquired, as the case may be. ${ }^{24}$

\section{Effect of registration}

If a charge which requires registration is not registered, the company, and every officer in default, is liable to a fine. ${ }^{25}$ Section 99(11) of the Companies Act also provides that:

"If the particulars and documents relating to a charge that are required by this section to be lodged with the Registrar are not lodged within the time required:

(a) the charge shall be void against the liquidator and any creditor of the company; and

(b) the full debt secured by the charge shall become payable immediately by the company." 26

In Mwila it was emphasized that these provisions only apply to companies and not to an individual with a claim over company property. The court stated that the statutory obligation and duty to comply with registration requirements fall on the company, especially in light of section 99(11) which stipulates the consequences of failure to register a charge that is required to be registered. In this regard the consequences for non-registration put the interests of creditors ahead of the company's interests. However, this does not paint the complete picture as it ignores the consequences for non-registration in relation to the conflicting claims of third parties. Clearly, an unregistered interest is

22 Companies Act, sec 97(2).

23 Id, sec 98(1).

24 Id, secs 99(1)(d) and (2)(b).

$25 \mathrm{Id}, \sec 97(4)$.

26 Also, note that sec 348 provides: "A floating charge on the undertaking or property of the company created within twelve months before the commencement of the winding-up shall, unless it is proved that the company immediately after the creation of the charge was solvent, be invalid except to the amount of any cash paid to the company at the time, or subsequently, in consideration for the charge, together with interest on that amount at the rate fixed by the terms of the charge." 
invalid against subsequent secured creditors and the liquidator. ${ }^{27}$ The objective of registration as reflected in the sanctions provided in section 99(11) is to give notice "of a specific security interest so as to bind third parties acquiring rights over the assets given as security, and thereby preserve the secured creditors' priority". ${ }^{28}$ This raises two sets of issues over the decision in Mwila, namely the exemption from registration of a mortgage created by deposit of documents of title and the onus to register.

The first is summed up by Roy Goode when he states that, due to the nature of "the criteria for registrability of an interest and the sanction for nonregistration ... [t] he result is that in order to preserve the validity of his security vis-à-vis third parties the creditor is required to register it in the Companies Registry even where it is a possessory security (eg, a mortgage protected by deposit of the title deeds) or is registrable in some other, specialist, register, such as the Lands Registry". ${ }^{29}$ Goode was expressing dissatisfaction with some equivalent provisions (namely sections 399(3) and 395(1)) of the UK Companies Act 1985 to the effect that: "Since the object of registration is to give notice of the security interest to third parties, failure to register ought not in principle affect the enforceability of the security against the debtor himself". ${ }^{30}$ In other words, the mismatch between the requirement to register and the sanction imposed for failure to do so has far reaching consequences for those on whom the legal obligation to register does not rest.

The second point follows from this conclusion. It is clear that, according to statute, the onus to register falls on the company. ${ }^{31}$ However, the creditors owe it to themselves to protect their interests through registration at the Companies Registry in order to preserve the validity and priority of their security. In this regard, registration, which is not merely a perfection requirement, is the duty of the person taking the charge. It is of no help to a creditor to allege failure to register on the part of the company when the legal sanction imposed for non-registration at the latter's behest is merely a fine. It is important to understand though that this scenario is in accord, and as such can be reconciled, with the intended objective of the law to create a reporting function to provide public information as to the general state of a company's affairs, and in particular the company's financial position.

The insistence by the court in Mwila that the statutory consequences for failure to register only "apply to companies and not to an individual who holds an equitable mortgage by way of deposit of title deeds" must be treated cautiously because, although the obligation to register rests on the company,

Goode Commercial Law, above at note 14 at 651.

Ibid.

Ibid. Note that all the UK company law provisions of the 1985, 1989 and 2004 acts have been consolidated in the Companies Act 2006. At the time of writing, the British government had announced that the final implementation date of the Companies Act 2006 would be postponed from 1 October 2008 to 1 October 2009

Goode, ibid.

See sec 99(2), Companies Act. 
there are wider implications for creditors in relation to third parties with competing interests. Given that section 99 is aimed at the transactions and not just the documents in respect of charges envisaged under part V of the Companies Act and that the law requires both "the particulars and documents relating to a charge ... to be lodged with the Registrar", 32 it is important to note that the particulars or a copy of the security document are only required to be lodged "if the charge is created or evidenced by an instrument". ${ }^{33}$ Also, the definition of the word "charge" includes mortgages ${ }^{34}$ and covers "a[ny] charge on land". ${ }^{35}$ Without having regard to particular circumstances, it may therefore not be entirely accurate to suggest unequivocally that an equitable mortgage by surrender of title deeds is not registrable. These circumstances may include the existence of a memorandum of deposit or surrender of title deeds, in which case the transaction would be evidenced by an instrument. The absence of such evidence would presumably give rise to a different outcome. It is not unlikely that this was the gravamen of the reason for the decision in Mwila.

The terms of section 99 are clear as to the consequences for non-registration, and also regarding the requirement for particulars, not just documents, to be lodged. In principle, it is unusual to require registration of a possessory security. The physical possession of a document of title by the creditor is considered to be the strongest form of perfecting the creditor's security interest; registration is thought to be unnecessary since the absence of the deeds puts third parties dealing with the debtor on inquiry. On the other hand, registration of a possessory security may offer peremptory protection for those taking that security, particularly in the case where fake documents of title may be involved. The act, therefore, appropriately provides a voluntary registration scheme under section 99(10) which allows for "lodgement of documents ... on the application of any person interested in the charge". ${ }^{36}$ However, when the law invites the conclusion that registration is more than just a matter of perfection, but also affects validity, there is little comfort in the provision of voluntary registration as an option for the chargee. This is because, through no fault of their own, creditors face the daunting prospect that a charge under which they have taken security may be deprived of priority or worse still be voided.

32 Id, sec 99(11).

33 Ibid. Subsec (2) contains the actual requirement obliging companies to register, while subsec (3) stipulates the particulars required for the purposes of registration.

34 Id, sec 2.

35 See id, sec 99(1)(e). Note that subsec (6) provides: "Debentures entitling the holder to a charge on land shall for the purposes of this section be deemed not to be an interest in land." Sec 395 of the UK Companies Act 1985 creates similar mandatory registration requirements for charges by companies created by the deposit of title deeds.

36 According to sec 99(10), "that person shall be entitled to recover from the company the amount of any fees properly paid by him to the Registrar on the lodgement". The documents for this purpose include the prescribed form for particulars as required by sec 99 (3) and particulars or copies of the instrument creating or evidencing the charge. 


\section{PRIORITIES}

Creditors taking security must make a point of establishing by due diligence that there are no pre-existing interests to which their own security will be subordinated. They also need to take appropriate measures to perfect their security interest to avoid it being overridden by a debtor's subsequent disposition. While subordination to competing security interests may not be fatal, the existence of an absolute superior opposing interest extinguishes the security interest altogether. ${ }^{37}$

\section{Common law and equity ${ }^{38}$}

The general rule established through case law is that priority among competing interests is determined by the order in which they were created, provided that a legal estate has preference over an equitable interest. ${ }^{39}$ Generally, where there are competing equitable interests, the first in time prevails. ${ }^{40}$ As Lord Macnaghten said, "[i]t is the essence of ... a [floating] charge that it remains dormant until the undertaking charged ceases to be a going concern". ${ }^{41}$ Thus, since a "floating charge is merely an incomplete charge until it crystallizes any later fixed legal or equitable charge created by the company - even in favour of a person who has actual notice of the floating charge - will rank in priority unless the floating charge had crystallized and the later chargee had notice of crystallization before the later charge was created". ${ }^{2}$ Where a subsequent floating charge is created over identical assets, it will be ineffective

37 For more analysis, see Goode Commercial Law, above at note 14 at 51 .

38 The common law and the doctrines of equity are applicable in Zambia subject to the provisions of the constitution and any other written law. See English Law (Extent of Application) Act, cap 11 of the Laws of Zambia, sec 2(a) and (b).

39 This is in keeping with the maxim that "where the equities are equal, the law prevails".

40 Dearle $v$ Hall (1828) 3 Russ 1 [1824-834] All ER 28. This case established a controversial English common law rule to determine priority between competing equitable claims to the same asset. The beneficial owners of a trust of land mortgaged their beneficial interest to two different mortgagees. The question arose as to which mortgage had priority. It was held that the deciding factor was the order in which the mortgages had been notified to the trustees, regardless of the order in which the mortgage was granted. This is provided that the holder of the subsequent interest takes title without notice of the first interest, in which case the former obtains priority. It was subsequently extended to all assignments of a beneficial interest by sec 137 of the UK Law of Property Act 1925. The rule has been severely criticized. For example, see Lord Macnaghten in Ward $v$ Duncombe [1893] AC 369, stating [at 393]: "I am inclined to think that the rule in Dearle $v$ Hall has on the whole produced at least as much injustice as it has prevented"; see also F Oditah Legal Aspects of Receivables Financing (1991, Sweet \& Maxwell); Goode Commercial Law, above at note 14 at 652, stating that "[i]t is high time that the rule in Dearle v Hall was abolished".

41 Per Lord Macnaghten in Governments Stock and Other Securities Investment Co Ltd v Manila Pty Co (1897) AC 81 at 86.

42 Lingard Bank Security Documents, above at note 10 at 156 and 159; Re Hamilton's Windor Ironworks, ex p Pitman and Edwards (1879) 12 Ch D 707. Also, see Goode Commercial Law, above at note 14 at 686, stating (at 665): "The peculiarity of the floating charge is that, 
in relation to the existing floating charge if it goes against the intention of the earlier charge. ${ }^{43}$ This position is not founded on the existence of a negative pledge clause in the security document. However, the company may create a prior ranking floating charge over part of the assets. ${ }^{44}$ Here, the specificity of the charge and not that of its subject matter will influence priorities. ${ }^{45}$

These rules have a different application where the floating charge has a negative pledge clause against the creation of higher ranking charges, provided the affected third party had notice of the pledge. ${ }^{46}$ Still, not all those taking with notice of the security interest are necessarily affected by it. ${ }^{47}$ It is now conventional wisdom in legal drafting to include such a restriction in debentures without which the floating charge would be virtually useless. The bona fide holder of a later legal charge still has priority over an earlier equitable charge as long as they are without notice. Similarly, where a floating charge contains a clause restricting or prohibiting prior or equal ranking, a subsequent fixed chargee or mortgagee shall still have priority provided they had no notice of the restrictive covenant. ${ }^{48}$ Mere registration of the floating charge does not constitute notice that it contains a clause with a negative pledge. ${ }^{49}$ In any event, notice of a debenture is not necessarily notice of its contents. ${ }^{50}$

There are further considerations where one of the conflicting charges is created by mortgage, as was the case in Mwila. The rules of priority with regard to mortgages were changed following the introduction of the UK Law of Property Act 1925 (LPA). Briefly, where the mortgages fall in the same class, for example if both are equitable mortgages, the first in time will have priority. This is so because "where the equities are equal, the law prevails", and here the old rule that the first in time has priority prevails. ${ }^{51}$ However, under the LPA no distinction is made between legal or equitable mortgages. The question is whether the mortgage is registrable as a land charge.

contd

by virtue of the powers of disposition left to the debtor company, it is in principle subordinated to a subsequent fixed charge, whether legal or equitable".

43 Re Benjamin Cope \& Sons Ltd, Marshall $v$ Benjamin Cope \& Sons Ltd [1914] 1 Ch 800; Re Household Products Co Ltd (1981) 124 DLR (3d) 325.

44 Re Automatic Bottle Makers Ltd, Osborne v Automatic Bottle Makers (1926) Ch 412.

45 JH Farrar, NE Furey and BM Hannigan Farrar's Company Law (3rd ed, 1991, Butterworths) at 277 .

46 Goode Commercial Law, above at note 14 at 686-87.

47 Id at 666.

48 Dearle $v$ Hall (1828) 3 Russ 1; Wheatley $v$ Silkstone $\&$ Haigh Moor Coal Co (1885) 29 Ch D 715.

49 Under sec 24 of the Companies Act, notice or knowledge of the contents of a document concerning a company is not to be presumed by reason only that the document has been lodged at the Companies Registry or is held by the company and available for inspection. Also, see Re Valletort Sanitary Steam Laundry Co Ltd, Ward $v$ Valletort Sanitary Steam Laundry Co Ltd [1903] 2 Ch 654; Re Standard Rotary Machine Co (1906) 95 LT 829.

50 Halsbury's Laws of England, above at note 7, vol 16, para 1327.

51 R Megarry and HWR Wade The Law of Real Property (4th ed, 1977, Stevens \& Sons) at 959. 
If registration is required but has not been done, then priority is lost over a subsequent encumbrancer and, indeed, the mortgage is void against a later purchaser. ${ }^{52}$ Mortgages that are not required to be registered, such as those created by deposit of documents of title, do not come under this statutory regime and their priority is governed by the rules applicable before the introduction of the LPA. ${ }^{53}$ This was the reasoning adopted in Mwila. Although the court did not establish a basis for the applicability or relevance of the LPA to Zambia, a similar outcome would presumably be achieved provided the mortgage in question was not "created or evidenced by an instrument".

\section{Statutory scheme}

Section 101 of the Companies Act sought to change the normal rules for determining priority in cases where there was conflict. The Companies Act created ten categories of charges which require registration. ${ }^{54}$ These categories refer to specific kinds of assets in respect of which security can be taken. For those charges that fall within the types required to be registered, the rank of priority is determined and guaranteed according to the time of registration. Where there is conflict between competing rights holders, the first to file prevails. Since in this case the time of lodgement at the Companies Registry establishes the point of priority, the date of creation of the security is irrelevant. If the charges involved are of the kind required to be registered under the Companies Act, their nature or characterization is also irrelevant for the purposes of determining priority. In essence, whether a charge is required to be registered depends on the kind of property being charged, ie the type of asset must be stipulated in one of the ten statutory categories.

Where the charges do not come within the scope of section 101, the rule in that section does not apply. Also, the rule will clearly not apply where there are special rules of priority set out in another statute. ${ }^{55}$ If a charge, other than a floating charge, gives security over company property that is of a kind envisaged under part V, and also over other property (for which registration is not required), the applicable point of priority will be the time of registration for the former but not for the latter. ${ }^{56}$ For other property not covered by section 101, the common law rules will apply. Hence, a charge or entitlement which is otherwise not registrable, and presumably stronger, will not lose priority. In other words, mere registration of a floating charge will not oust the priority of a later fixed legal or equitable charge provided the latter does not fall within the ambit of section 99(1).

In Mwila, the security held by equitable mortgage was created before the floating charge (which was duly registered), and long before the appointment

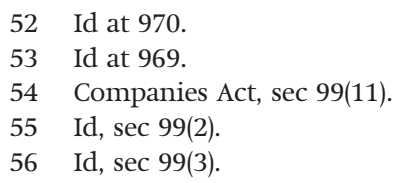


of a receiver under the charge. ${ }^{57}$ Although the latter was merely an equitable security before the crystallizing event, the equities were not equal since the former was fixed. The court therefore held that the mortgage had maintained its priority status over the floating charge. In any event, the surrender of title deeds occurred before the charge was created.

The holding of the Supreme Court to the effect that an equitable mortgage by deposit of title deeds did not lose priority to a floating charge which was duly registered warrants further comment. The court opined that sections 99 and 101 did not apply to an equitable mortgage by way of deposit of title deeds held by an individual. It stated in particular that section 101 is self-explanatory in creating priority by registration only among those charges required to be registered under part $\mathrm{V}$ of the Companies Act. It must be reiterated here that the point is not so much that the chargee is an individual, but whether the charge is of the kind that is required to be registered. The equitable mortgage was not registrable as there was no document to register and, in any event, if there was anything to register it was the company's responsibility to do so. The consequences for non-registration, vis-à-vis validity or priority, are not vitiated by the mere fact that the obligation to register rests with the debtor company.

If indeed the requirement for registration captures both charge documents and particulars, then one would argue that any transaction which involves the creation of a charge over the property or undertaking of a company falling within the purview of section 99(1) is subject to those requirements. In Mwila, it was made clear that the individual chargee held his interest "under a loan agreement which was secured by equitable mortgage by way of deposit of the Title Deeds". ${ }^{8}$ One is left to wonder whether this agreement was not reduced to writing, thereby satisfying the statutory prescription that "if the charge is created or evidenced by an instrument" 59 then registration is required. With regard to the rules for determining priority involving mortgages, it will suffice to note that the exemption which applies to security by deposit of title deeds under the LPA refers to charges over unregistered land. It is because the land is unregistered that the charge is deemed to be protected through the surrender of the title deeds. Assuming for the sake of argument that the LPA were applicable to Zambia, it is important to bear in mind that the definition of the word "charge" includes mortgages and that registration is required for "a charge on land". ${ }^{60}$ Although the court dwelt

57 Note that the decision in Re Sapco (above at note 3) is inconsistent with the superior precedent in Mwila on the applicability of the common law rules.

58 Mwila, above at note 5.

59 Companies Act, sec 99(11). The word "instrument" must obviously be taken to mean a "legal instrument", in which case it refers to any document, however duly executed and authenticated, for the purpose of stating some contractual relationship or granting some right. EA Martin and J Law (eds) A Dictionary of Law (6th ed, 2006, Oxford UP) at 279 define an "instrument" as "a formal document, such as a will, deed, or conveyance, which is evidence of [for example] rights and duties".

60 See Companies Act secs 2 and 99(1)(e) respectively. Sec 2 of the Land and Deeds Registry 
on the issue, it did not point to any basis to suggest that this UK statute is in force in Zambia. In the absence of such validation, the applicable rules would be those existing at common law before the changes introduced by the UK statute, subject of course to the provisions of the Companies Act. ${ }^{61}$

\section{CONCLUSION}

This article has discussed the nature of the legal requirements for registration of company charges under the Zambian Companies Act. There seems to be a lack of conceptual symmetry between the registrability criteria and the sanctions for failure to register, vis-à-vis the objectives of registration. This raises concerns and some doubt as to the suitability of the statutory scheme. ${ }^{62}$ While registration assures priority, it clearly also serves to protect the security from being void against subsequent encumbrances. ${ }^{63}$ Thus, it is ultimately the creditors' responsibility to act diligently to secure their interests. There can be little doubt that charges are important business devices. As Goode has observed, "[t]he purpose of the floating charge has always been to provide the creditor with some form of security interest, despite the debtor's dealing powers, while ensuring that third parties acquiring rights in the subject matter of the charge obtain a title free from the floating charge". ${ }^{64}$ However, a clear set of rules for determining priority is important for maintaining a balance between the interests of the debtor company to deal with its assets in the ordinary course of business, and the interests and competing rights of creditors. These rules have historically depended on the courts' characterization of charges but this has caused difficulties in relation to the rights of preferential creditors. The introduction of a statutory registration scheme was meant to address some of these problems by simplifying the rules on priority. Therefore, the law can scarcely afford to be confounded by judicial precedent. If nothing else, the need to preserve the law's original objectives, in seeking to create a suitable statutory scheme, would be sufficient reason for further review and reform.

contd

Act (cap 185) provides that a "mortgage includes a deposit of title deeds or documents with the object of creating an equitable mortgage on the property comprised in such deeds or documents and any charge".

61 The argument can be framed differently by arguing that the applicable rules are the pre-1925 rules in any event, since the exemption relating to security by deposit of title deeds only applies to charges over unregistered land.

62 See Goode Commercial Law, above at note 14 at 689.

63 Companies Act, sec 99(11)(a).

64 Goode Commercial Law, above at note 14 at 689. 